\title{
Effectiveness Of Allotment Penalty Imposed By Judge In The Case Of Children For A Child Protection As Victims (Case Study at State Court of Sumber)
}

Didi Wahyudi Sunansyah ${ }^{1}$ and Aryani Wirasari ${ }^{2}$

\begin{abstract}
The formulation in this study were 1) How allotment setting penalty in child protection legislation in order to protect the child as a victim? 2) How is the effectiveness of the penalty in the Child Protection Act?

Method sociological approach juridical law and specification in this study were included descriptive analysis. Even sources and types of data in this study are primary data obtained from interviews with field studies Supervising Officers Society Child (PK Child) of the Penal Hall Cirebon and Head of Correctional Cirebon, And secondary data obtained from the study of literature. Data were analyzed qualitatively. The problems studied by the theory of progressive legal protection and law.

Based on the results of this study concluded under Appropriation settings Criminal Penalty In Child Protection Act is not describe protect children as victims, because the penalty to be paid by the convict is intended for countries not intended for children who are victims of crime. Appropriation effectiveness Criminal Judge Penalty That Dropped In Case of Children in the Context of the Protection of Children As Victims are Criminal penalties in the Law on Child Protection was not effective in reality, as more convicts chose imprisonment in lieu of penalty are not paid, compared to paying the penalty, it has implications for the expenditure of state finances are more likely to pay for convicts in prisons and to make prisons more crowded or over capacity.

Keywords: Effectiveness; Penalty; Justice; Protection; Child.
\end{abstract}

\section{Introduction}

Protection to victims of crime in Indonesia should get serious attention. This is addressed by the government by issuing Act No. 13 of 2006 on the Protection of Witnesses and Victims. However, with the passage of time, the law is considered to have some weakness in the value of significant enough, so it is necessary to amend the Act ${ }^{3}$. The Act No. 31 of 2014 which is to amend Act No. 13 of 2006 on the Protection of Witnesses and Victims ratified by the Government and enacted to correct weaknesses in the Act No. 13 Of 2006. Specifically for the legal protection of children, the state gives attention by enacting Act No. 35 of 2014 which is Amendment Act No. 23 of 2002 on the Protection of Children (BAL). The amendment is to reinforce the importance weighting of criminal sanctions and penalties for the perpetrators of crimes against children to provide a deterrent effect, as well as to encourage concrete measures to recover physically. ${ }^{4}$

Article 4 of Act No. 35 of 2014 concerning amendments to the Act 23 of 2002 on the Protection of Children (BAL), states that "Every child has the right to live on growth,

\footnotetext{
${ }^{1}$ Student of Master of Law, Universitas Islam Sultan Agung Semarang and Indonesian Police Member, email: sunansyahwahyudi@gmail.com

${ }^{2}$ Lecturer of Master of Law, Sultan Agung Islamic University (UNISSULA), Semarang

${ }^{3}$ Explanation of the Law of the Republic of Indonesia Number 35 Of 2014 regarding Amendment to Act No. 13 of 2006 on the Protection of Witnesses and Victims.

${ }^{4}$ Explanation of the Law of the Republic of Indonesia Number 31 Of 2014 regarding Amendment to Act No. 23 of 2002 on Child Protection.
} 
development, and participate fairly in accordance with human dignity and protection from violence and discrimination".

The purpose of the changes BAL that reinforce the importance of weighting the criminal sanctions of penalty, namely to encourage concrete steps to restore the physical, psychological and social development as a victim, apparently not reached, but a penalty is augmented, needs to be re-whether these objectives appropriate, consistent and in harmony with the objective that in principle BAL anti-exploitation of children. In BAL renewal that has suffered two renewals, the criminal penalties for perpetrators of crimes against children is augmented, both for people as perpetrators or corporation, but not a single article that specifies that the penalty imposed are intended for children who are victims of crime, but intended for the State, has rights to get protection from abuse exploitation, both economic and sexual, with no attention to the State of the child victims of criminal offenses related to the imposed penalty for the perpetrators of criminal acts against children, it is as if the State has made the exploitation of child victims of crime, because all the observations writer in jurisdiction of the courts in Cirebon, there never was a judge who dropped the criminal penalties against perpetrators of criminal acts against children, that the penalty is intended for children who are victims of crime.

Based on the above background exposure, the research problem is formulated as follows: How allotment setting penalty in child protection legislation?; How can the effectiveness of criminal penalty designation imposed a judge in the case of children in the context of the protection of children as victims?

\section{Research methods}

The method used is a sociological juridical approach. Juridical sociological (socio-legal approach) intended to study and examine the reciprocal relationship in real terms associated with social variables other. specification of research used in this research is descriptive analysis, the research aimed to obtain a clear and systematic about the circumstances or the facts of the problems studied and dipejari as something intact ${ }^{5}$,Even sources and types of data in this study are primary data obtained from interviews with field studies Supervising Officers Society Child (PK Child) of the Penal Hall Cirebon and Head of Correctional Cirebon, And secondary data obtained from the study of literature. Data were analyzed qualitatively. The problems studied by the theory of progressive legal protection and law.

\section{Results and Discussion}

\subsection{Appropriation Settings On Criminal Penalty In Child Protection Act}

The birth of the progressive law departs from the idea of law or legal theory that had preceded the ${ }^{6}$ First, the flow of natural law. Friedman said legal history Nature is the history of mankind in his quest to find the so-called absolute justice. Second, the flow of sociological jurisprudence. Exphonen, with the core thinking expressed a good law is the

\footnotetext{
${ }^{5}$ Mukti Fajar ND., dkk, 2010, Dualisme Penelitian Hukum Normatif dan Empiris, Pustaka Pelajar, Yogyakarta, p. 192.

6 Mahrus Ali, 2013, Membumikan Hukum Progresif, First Edition, Aswaja Pressindo, Ngaglik Sleman Yogyakarta, p. 61-69.
} 
law in accordance with law who live in the community. As the law reflects the values that live on the victim. Third, the flow of legal realism. John Chipman gray states realism law is a study of the law as a really significantly implemented, rather than simply as a law that only the number of rules contained in legislation was never implemented. The flow of legal realism, normative nature of law must be ruled out, because the law is essentially a pattern of behavior. Fourth flow responsive law presented by Nonet and shelznick, the flow is explained, the law should be used as a way to satisfy justice and the interests of victims. The fifth critical legal studies (critical legal studies) was initiated by Roberto M. Unger. This flow departs from dissatisfaction with the liberal legal tradition-laden formalism and objectivism. Of 5 (five) flow over Sajtipto Raharjo agree that the law is a rule for men as well as the law created to serve and happy man. In this case the protection of victims, because it allows the victim to have violated by perpetrators deservedly get protection given to the victim. Juridical problems arising victim is not their attention and service to victims of crime, this is not a sign or lack of justice and the development of the welfare society ${ }^{7}$, when viewed law for humans, the more priority rules for people deprived independence that is the victim. For the completion of the tensions between the parties (the perpetrator and victim) criminal acts carried out directly between them without the intervention of a third party. However, after the existence of the state embraced as the regulatory body for life community, then the resolution of conflicts between perpetrators and victims of crime be state authority ${ }^{8}$,

Hereinafter the victim's position was taken over by the State, through the law enforcement officers, are empowered to combat criminal acts in the community ${ }^{9}$, In fact carried out by the State does not always satisfy the victims, as well as the perpetrator criminal act ${ }^{10}$, often in the imposition of criminal sanctions is considered unfair because it is very light and the victim does not receive compensation corresponding to the loss suffered by the victim, to protect victims of criminal acts does need to be instilled more in, because so long riveted protection of suspects or perpetrators. ${ }^{11}$

\footnotetext{
${ }^{7}$ Rena Yulia, 2013. Viktimologi Perlindungan Hukum Terhadap Korban Kejahatan, Second Printing, Graha Ilmu, Yogyakarta, p. 57

${ }^{8}$ Mudzakir stated that the Country, In It's the police prosecutor, Has The Dominant Role And Reaction To monopoly Criminal Offenders With Being Of Society Or vice Legitimate Interests Of Public, Truly Through The Long Struggle Has Take Over Role of Victim As a Person Suffering Due to Crime. Had Recognizing Netherlands Position Independent Party as Victim In the Criminal Justice System. But In 1838 Victims of The Independent Position Known As Partie Civile Eliminated. See Mudzakir "Posisi Hukum Korban Kejahatan Dalam Sistem Perdilan Pidana". Disertasion, Jakarta: Postgraduate of Law Faculty, 2001, p. 2, 152-153 and p. 383.

${ }^{9}$ Wijono Prodjodikoro stated Criminal Law Enforcement Essentially seorag Will Not Dependent On Individuals, Yang Incorcreto Direct Disadvantaged, Rather Suit To State sebegai Representation Of Public Interest. As soon as the State Authority with Takeover Conflict Happens Between Criminal Offenders with Victims, Offenders in the Conflict Between Being Or Keentingan with the State Public. Current State Being the Only Victim Of A Crime. Subsequently See Wirjono Prodjodikoro, 2003, "Asas-Asas Hukum Pidana, Refita Aditama, Jakarta, p. 155.

${ }^{10}$ Barda Nawawi Arif stated "The statement of criminal law, among others because very stiff and very limit the criminal that can be selected, so less giving allowance for judge to choosing a criminal who considered appropriate for perpetrators of the Crime"'", see Barda Nawawi Arief, 2005, Beberapa Aspek Kebijakan Penegakan Dan Pengembangan Hukum Pidana, Citra Adi Bakti, Bandung, p. 73-74.

${ }^{11}$ Results Interview with Nuridin, SH., MH, as Head of the Penitentiary on December 20, 2019, in the Bapas Office of Cirebon.
} 
Based on the wording of Article 71D are explained clearly that the criminal penalties with a child victim, criminal penalty are intended for the State not to the child, while the child victim can only apply for restitution for the losses suffered by referring to Government Regulation No. 43 Of 2017 on the Implementation of Restitution for children who Become victims of Crime, thus the child may otherwise be exploited by the State, because the penalty are intended for the State, while child victims may only be filed restitution if it refers to the regulation course of a very long, long time because of the bureaucracy is quite complicated and costly, not impossible that a child victim would fall victim restitution costs if the claim is not successful.

Based on the foregoing, the penalty in the case that the victim child, the allotment of these penalty is for the State not for children who are victims of crime, so these provisions should not be such that must be reconstructed in order to impress the imposition of criminal penalties that value the reproduced the unimpressive child Protection Act is legislation that exploits children for the sake of Tax State Revenue (non-tax). ${ }^{12}$

From the point of view of the theory of legal protection Appropriation settings Criminal Penalty In Child Protection Act that to know the state laws and regulations governing the protection of children to do with criminal penalties against the perpetrators of criminal acts against children. From the standpoint of the progressive legal theory that the law was not only executed with spiritual intelligence. Law must be run with determination, empathy, dedication, a commitment to the plight of the nation to dare find other ways to the welfare of the people

Appropriation settings Criminal Penalty In Child Protection Act is not describe protect children as victims, because the penalty to be paid by the convict is intended for countries not intended for children who are victims of crime.

\subsection{Appropriation Effectiveness Of Criminal Penalty Which Judge Dropped In Case Of Children In The Context Of The Protection Of Children As Victims}

Children who become victim of a criminal offense or called Children Victims are children who are under 18 (eighteen) years physic make children suffering, mental anguish, and / or economic loss caused by a criminal act ${ }^{13}$. Children as the victims can suffer physical harm as well as non-physical losses. Physical losses may be defects, injuries and even death. Nonphysical losses may be mentally disturbed children, as well as the fear that there is no ending perceived by children. Mattalata ${ }^{14}$ found the form of aid efforts on the victim is not a liability to the perpetrator, but also an obligation for citizens as well as obligations of the state. Protection of the victim as an effort to provide fair treatment for both children as victims, offenders and the community which is the hope that aspired too.

Victims of a crime that is essentially the most suffered party to a criminal act, it does not get as much protection as that given to the perpetrator Act an offense as stated by Andi

\footnotetext{
${ }^{12}$ Results of interviews with Arie Susanto, PK Child of Correctional Centers (Bapas) Cirebon, the interview was conducted on December 19, 2019, at $14.15 \mathrm{pm}$

${ }^{13}$ Act No. 11 of 2012 on the Criminal Justice System Child, Article 1, paragraph 4.

${ }^{14}$ Yazid Effendi, In Nurini Aprilianda, Perlindungan Anak Korban Kekerasan Seksual Melalui Pendekatan Keadilan Restoratif, Volume 10, Nomor 2, August 2017, p. 312.
} 
Hamzah $^{15}$. "In discussing the criminal procedural law, in particular with regard to the human rights, there is a tendency to peel on matters relating to the rights of suspects without taking also into account the rights of victims of a crime." The low position of the victim of a crime in the handling of criminal cases, it is also stated by Prassell which states: "Victim was a forgotten figure in the study of crime. Victims of assault, robbery, theft and other offenses were ignored while police, courts, and academicians concentrated on known violators" ${ }^{\text {". } 16}$ The law on the protection of victims of crime is part of the protection of the public, can be realized through various means, such as through the provision of restitution and compensation to victims, medical services, and also in the form of legal aid ${ }^{17}$.

Ari Susanto ${ }^{18}$, SH., MH., Clerk Supervisor Community Center (PK Child) from the Institute of Corrections Cirebon, stating that the child victim in fact necessary and considered only during the judicial process take place, after the trial expires it will be forgotten, the suffering that continued throughout his life, for example victims become permanently disabled. Such a situation is as it should be considered and taken into account in the change in the law on child protection in the future.

While Nuridin ${ }^{19}$, SH., MH., Head of the Correctional Cirebon deliver, in terms of providing protection to children who are victims of criminal offenses in the future, and in order to meet the objectives of the promulgation of Law on Child Protection, related to penalty and / or restitution thinks there options as follows: Restitution; Penalty.

Effectiveness of criminal penalties in the legislation on child protection is a penalty in the Law on Child Protection was not effective in reality, as more convicts chose imprisonment in lieu of penalty are not paid, compared to paying the penalty, it has implications for the financial outlay State greater to finance the convict in a correctional institution and to make prisons more crowded or over capacity.

\section{Closing}

\subsection{Conclusion}

- Appropriation settings Criminal Penalty In Child Protection Act is not describe protect children as victims, because the penalty to be paid by the convict is intended for countries not intended for children who are victims of crime.

- Effectiveness allotment of Criminal Penalties The Dropped Judge In Case of Children in the Context of Child Protection For Victims In the State Court of Sumber is the courts and organization is part of the legal structure, meaning that if the trial judge is not authorized to impose the penalties imposed for perpetrators of criminal acts of a child, whether

\footnotetext{
${ }^{15}$ Andi Hamzah, 1986, Perlindungan Hak-hak Asasi Manusia dalam Kitab Undang-Undang Hukum Acara Pidana, Binacipta, Bandung, p. 33.

${ }^{16}$ Haryanto Dwiatmodjo, "Pelaksanaan Perlindungan Hukum Terhadap Anak yang Menjadi Korban Tindak Pidana di Wilayah Hukum Pengadilan Negeri Banyumas", Jurnal Dinamika Hukum, Vol. 11, No. 2, May 2011, p. 202.

${ }^{17}$ Didik M Arif Mansur, Elisatris Gultom, 2006, Urgensi Perlindungan Korban Kejahatan Antara Norma dan Realita, Rajawali Pers, Jakarta, p. 31.

${ }^{18}$ Results of interviews with Arie Susanto, PK Child of Correctional Centers (Bapas) Cirebon, the interview was conducted on December 19, 2019 in Bapas Cirebon.

${ }^{19}$ Results Interview with Nurdin, SH., MH, as Head of the Penitentiary on December 20, 2019, in the Bapas Office of Cirebon.
} 
penalty State imposed or intended for children, the trial judge as a structural element of law will not work in providing protection to children who are victims of crime. Criminal penalties in the Law on Child Protection was not effective in reality, as more convicts chose imprisonment in lieu of penalty are not paid, compared to paying the penalty, it has implications for the expenditure of state finances are more likely to pay for convicts in prisons and to make prisons more crowded or over capacity.

\subsection{Suggestion}

- Within the framework of reform of criminal law in the future, should be criminal penalties for criminal acts against children or child victims of the penalty imposed on the convict can be considered to be given or dedicated to the child victims, either in whole or in part, and the authority to impose the penalties was given to the judge by Supervising the research community of the community of Correctional Centers.

- If the penalty are retained for the benefit of the State and the child victim is only granted the right to apply for restitution, should the reform of criminal law in the future, the fulfillment of the right to restitution, whether requested or not requested by the child victim is used as a liability the Prosecution to file a restitution along the process criminal justice at the State Court to consider the research community of Supervising community Correctional Centers.

\section{References}

[1] Andi Hamzah, 1986, Perlindungan Hak-hak Asasi Manusia dalam Kitab UndangUndang Hukum Acara Pidana, Binacipta, Bandung

[2] Barda Nawawi Arief, 2005, Beberapa Aspek Kebijakan Penegakan Dan Pengembangan Hukum Pidana, Citra Adi Bakti, Bandung

[3] Didik M Arif Mansur, Elisatris Gultom, 2006, Urgensi Perlindungan Korban Kejahatan Antara Norma dan Realita, Rajawali Pers, Jakarta

[4] Haryanto Dwiatmodjo, "Pelaksanaan Perlindungan Hukum Terhadap Anak yang Menjadi Korban Tindak Pidana di Wilayah Hukum Pengadilan Negeri Banyumas", Jurnal Dinamika Hukum, Vol. 11, No. 2, May 2011

[5] Mahrus Ali, 2013, Membumikan Hukum Progresif, First Edition, Aswaja Pressindo, Ngaglik Sleman Yogyakarta

[6] Mudzakir "Posisi Hukum Korban Kejahatan Dalam Sistem Perdilan Pidana". Disertasion, Jakarta: Postgraduate of Law Faculty, 2001

[7] Mukti Fajar ND., dkk, 2010, Dualisme Penelitian Hukum Normatif dan Empiris, Pustaka Pelajar, Yogyakarta

[8] Explanation of the Law of the Republic of Indonesia Number 31 Of 2014 regarding Amendment to Act No. 23 of 2002 on Child Protection.

[9] Explanation of the Law of the Republic of Indonesia Number 35 Of 2014 regarding Amendment to Act No. 13 of 2006 on the Protection of Witnesses and Victims.

[10] Rena Yulia, 2013. Viktimologi Perlindungan Hukum Terhadap Korban Kejahatan, Second Printing, Graha Ilmu, Yogyakarta

[11] Wirjono Prodjodikoro, 2003, "Asas-Asas Hukum Pidana, Refita Aditama, Jakarta

[12] Yazid Effendi, In Nurini Aprilianda, Perlindungan Anak Korban Kekerasan Seksual Melalui Pendekatan Keadilan Restoratif, Volume 10, Nomor 2, August 2017 